\title{
Organizational Commitment and Organizational Citizenship Behavior of Preschool Teachers Based on their Employment Status
}

Özlem BAYRAK ${ }^{1}$

\author{
Mehmet Ali HAMEDOĞLU²
}

\begin{abstract}
This study was carried out to investigate the organizational commitment and organizational citizenship levels of preschool teachers on the basis of different variables. 254 preschool teachers were included in the research. "Organizational Commitment Questionnaire" and "Organizational Citizenship Questionnaire" were respectively used for determination of the organizational commitment and organizational citizenship levels of preschool teachers. Statistical analysis of the obtained data was performed using SPSS 22.0 data analysis software by use of Kruskal Wallis $\mathrm{H}$ and Mann Whitney U analyses. As a result of the conducted research, preschool teachers' organizational commitment was found to be at moderate levels, and their organizational commitment levels exhibited statistically significant difference based on their employment and educational status. Preschool teachers' level of displaying organizational citizenship behaviors was also found to be at moderate levels. Preschool teachers' organizational citizenship behavior levels exhibited no statistically significant difference based on educational levels and employment status.
\end{abstract}

Keywords: Preschool teaching, organizational commitment, organizational citizenship behavior

\section{INTRODUCTION}

Individuals carrying out their jobs at a professional level are committed to their profession rather than their affiliation. Therefore, their intention to stay in their job is closely associated with the extent to which their demands are fulfilled and they are satisfied. At this very point, organizations strive to maintain the environments and applications to support this relationship (Bayrak-Kök, 2006). Since organizations are in continuous competition, their competitiveness is mainly dependent on their employees. Employees that give their best to successfully fulfill the responsibilities they undertook help their organizations in achieving their goals (Çoban, 2015).

As an outcome of the relationship between organizations and employees, organizational commitment is an indication of the strength of the affection felt by employees towards their organizations. Commitment, however, is not a concept that can be imposed by organizations on their employees. For organizations, ensuring that their employees are content with their affiliations is as important as production of their goods and services, as a positive correlation is assumed to exist between organizational commitment level and organizations' performance. In this context, organizational commitment is considered to minimize the undesired consequences such as tardiness, intention to quit the job and absenteeism, thus making positive contributions to product or service quality (Eren \& Demirgöz-Bal, 2015).

In this context of relations, organizational commitment is an indication of the working performance perceived by others and determined by product criteria. On the other hand, the level of commitment

\footnotetext{
${ }^{1}$ MA Student at Sakarya University, Educational Administration and Supervision, ozlembayrak7@gmail.com

2 Dr. Sakarya University, Faculty of Education, mhamed@sakarya.edu.tr
} 
emerging on the basis of these relations may also result with withdrawal behaviors ranging from perceived job alternatives to quitting the job (Balay, 2000).

\section{Concept of Organizational Commitment}

Organizational commitment is a measure of employees' level of identifying themselves with their organization, adopting its principles, goal and values, endeavoring for organizational outcomes and their desire to carry on with their job (Bayrak-Kök, 2006). As also indicated by the definition, organizational commitment should be addressed on the basis of multiple factors instead of a single formation. Organizational commitment is closely related with involvement of an individual in an organization and his/her acquisition of an organizational identity. In other words, the concept of organizational commitment is about establishing social and psychological links between organizations and individuals, (Demirel, 2008), loyalty of employees to their organization and their efforts for its success (Doğan \& Kılıç, 2007).

The extent of the harmony between organizational and individual beliefs and values also determine the extent of the emotion of organizational commitment. In organizations where the feeling of organizational commitment is high, issues such as working performance, organizational confidence, job satisfaction, information sharing, and attendance are also at high levels. On the other hand, in organizations with low levels of organizational commitment, anti-productive behaviors such as workplace discrimination, organizational alienation, absenteeism, misuse of resources and information, mobbing and quitting the job become unavoidable (Demirel, 2009). In an organization, increased levels of organizational commitment helps employees in adopting their organization's objectives, identifying themselves with their organization, increasing their level of devotion, voluntarily establishing and maintaining organizational relationships and actively fulfilling their roles in their organization (Yazıcıoğlu \& Topaloğlu, 2009).

The concept of organizational commitment comprise of three dimensions, namely affective commitment, continuance commitment and normative commitment (Durna \& Eren, 2005). Information related to these dimensions is presented below.

Affective commitment: The factors indicating the affection of employees to their jobs include the attraction of the job, distinctiveness of the roles and the objectives, attendance, organizational confidence, equality, importance attached to individuals, and information sharing. Establishment of an organizational structure involving such factors is undoubtedly possible with an organizational culture supporting this structure and a role of leadership that is effective on motivating the employees (Doğan \& Kılıç, 2007). The concept of affective commitment is among the subjects widely discussed in the literature. Employees with a strong feeling of affective commitment adopt the objectives and values of their organization and maintain their commitment through making a tremendous effort to exceed what is expected from the organization. In this respect, the feeling of organizational commitment is the biggest expectation of organizations from their employees (Çöl \& Gül, 2005).

Continuance commitment: Continuance commitment is closely associated with the ability of employees to adopt the roles assigned for them in organizations, the preparedness for displaying the highest performance to fulfill their role. Determination of the employees' roles and establishment of a rewarding system for successful employees is essential to maintain a strong continuance commitment in an organization (Bakan, 2011). 
Normative commitment: Normative commitment is the type of organizational commitment which is based on employees' sense of obligation to remain in their jobs with an ethical duty consciousness (Meyer \& Allen, 1991). In this context, the concept of normative commitment is very closely related with the employees' tendency to be loyal to their organizations (Taşkın \& Dilek, 2010).

The common ground of the three dimensions constituting organizational commitment is their meaning as a link between employees and their organizations that minimizes the possibility of leaving their jobs. The quality of such link varies on the basis of these three mentioned approaches. Employees with high affective commitment stay in their jobs just because they wish so, employees with high continuance commitment stay due to their interests, and individuals with high normative commitment stay on the grounds that it has to be so, and that they believe in the strategy they follow. In some cases employees may feel a strong sense of obligation to stay in their organization, however, they may not be disposed to act accordingly. In other cases, employees may feel neither obligation nor necessity to stay in their organization, yet they may choose to do so (Çöl \& Gül, 2005).

\section{Organizational Citizenship Behavior}

On the basis of their reality, the behaviors of employees involving their positive actions except their roles and their negative avoidance behaviors are together defined as "organizational citizenship behaviors" (Kaplan, 2011). According to Çetin (2011) organizational citizenship behaviors involve voluntary actions of employees to exhibit constructive behaviors that include improving the efficiency and effectiveness of the organization, thus supporting its mission and goals, placing the organization's interests before individual interests, and introducing innovations and novelties for the organization. Basim and Şeşen (2015) defined organizational citizenship behaviors as "behaviors exhibited in favor of the organization without a specific order".

The voluntary nature of organizational citizenship behaviors prevents them from being an integrated part of formal job requirements. As these actions are carried out voluntarily, they are not regarded as a part of such requirements. In organizations formally rewarded behaviors are included in the employment contracts of employees; therefore these are also included in job requirements. In this respect, organizational citizenship behaviors should be regarded as assisting actions among employees as they are evaluated separately from job requirements in line with organizational operations. Accordingly, organizational citizenship behaviors are assessed separately from the formal role behaviors of employees as additional role behaviors (Çetin, 2011).

\section{METHOD}

In this research, investigation of organizational commitment and organizational citizenship behaviors of preschool teachers on the basis of their employment status and educational levels was aimed. The research was carried out in the form of observation assisted relational screening model.

\section{Participants}

Research population consists of preschool teachers carrying out their duty in Sakarya province as of 2016-2017 educational term, and the research sample consists of a total of 254 preschool teachers ( 7 male and 247 female). 


\section{Measures}

A questionnaire comprising of 3 sections was used during the data collection stage of the research. The first section of the used questionnaire involves the personal information form that aims to determine the demographic properties of the participants, the second section involves "Organizational Commitment Questionnaire" that aims to determine the organizational commitment levels of the participants, and the third section involves “Organizational Citizenship Behavior Questionnaire” developed by Demir (2007) to determine participants' level of exhibiting organizational citizenship behaviors.

\section{FINDINGS}

The findings obtained from the questionnaires are presented below with their respective tables and interpretations.

\section{Table 1.}

Descriptive Statistics Related to the Participants' Organizational Commitment Questionnaire Scores

\begin{tabular}{lccc}
\hline Sub-dimensions & $N$ & $X$ & $S S$ \\
\hline Affective commitment & 254 & 3.76 & .781 \\
Continuance commitment & 254 & 3.24 & .761 \\
Normative commitment & 254 & 3.15 & .741 \\
Organizational commitment & 254 & 3.38 & .569 \\
\hline
\end{tabular}

Participants' affective commitment level was found to be over moderate levels and their continuance, normative and organizational commitment was found to be at moderate level.

\section{Table 2.}

Comparison of Organizational Commitment Questionnaire Scores of Participants Based on Their Educational Status

\begin{tabular}{|c|c|c|c|c|c|c|c|}
\hline Sub Dimensions & Edu. Status & $N$ & $X$ & $S S$ & Rank ave & $x^{2}$ & $p$ \\
\hline \multirow{3}{*}{ Affective Commt. } & Associate degree & 19 & 4.36 & .681 & 182.29 & \multirow{3}{*}{20.883} & \multirow{3}{*}{.000} \\
\hline & Bachelor's deg. & 217 & 3.67 & .762 & 118.85 & & \\
\hline & Master's deg. & 18 & 4.26 & .667 & 174.00 & & \\
\hline \multirow{2}{*}{$\begin{array}{l}\text { Continuance Com- } \\
\text { mitment }\end{array}$} & Assoc. degree & 19 & 3.57 & .688 & 160.13 & \multirow{2}{*}{6.581} & \multirow{2}{*}{.037} \\
\hline & Bachelor's deg. & 217 & 3.18 & .752 & 122.68 & & \\
\hline
\end{tabular}




\begin{tabular}{llllllll}
\hline & Master's deg. & 18 & 3.50 & .840 & 151.17 & & \\
& Assoc. deg. & 19 & 3.51 & .600 & 168.08 & & \\
$\begin{array}{l}\text { Normative Com- } \\
\text { mitment }\end{array}$ & Bachelor's deg. & 217 & 3.11 & .747 & 122.88 & 7.258 & .027 \\
& Master's deg. & 18 & 3.17 & .743 & 140.42 & & \\
& Assoc. deg. & 19 & 3.81 & .462 & 183.24 & & \\
$\begin{array}{l}\text { Organizational } \\
\text { Commitment }\end{array}$ & Bachelor's deg. & 217 & 3.32 & .556 & 119.62 & 17.830 & .000 \\
& Master's deg. & 18 & 3.64 & .580 & 163.72 & & \\
\hline
\end{tabular}

As indicated by the table, affective, continuance, normative and organizational commitment degrees of the participants differ in a statistically significant way on the basis of their educational status $(p>0.05)$. The difference between affective commitment and organizational commitment sub-dimensions is attributed to the difference between the commitment levels of participants with associate-master's degrees, and those with bachelor's degree. The difference between continuance and normative commitment sub dimensions is ascribed to the higher commitment levels participants with associate degree than those with bachelor's degree.

Table 3.

Comparison of Organizational Commitment Questionnaire Scores of Participants Based on Their Employment Status

\begin{tabular}{lllllllll}
\hline Sub dimensions & $\begin{array}{l}\text { Employment } \\
\text { status }\end{array}$ & $N$ & $X$ & $S S$ & $\begin{array}{l}\text { Rank } \\
\text { ave. }\end{array}$ & $\begin{array}{l}\text { Rank } \\
\text { total. }\end{array}$ & $x^{2}$ & $p$ \\
\hline $\begin{array}{l}\text { Affective com- } \\
\text { mitment }\end{array}$ & subject to 657 & 180 & 3.74 & .779 & 125.43 & 22576.5 & \\
& not subject to 657 & 74 & 3.81 & .789 & 132.55 & 9808.5 & & .482 \\
$\begin{array}{l}\text { Continuance } \\
\text { commitment }\end{array}$ & subject to 657 & 180 & 3.16 & .765 & 120.35 & 21662.5 & & \\
normative & not subject to 657 & 74 & 3.42 & .726 & 144.90 & 10722.5 & & .015 \\
commitment & not subject to 657 & 180 & 3.06 & .739 & 118.39 & 21311.0 & & \\
Organizational to 657 & 74 & 3.37 & .705 & 149.65 & 11074.0 & & .002 \\
commitment & subject to 657 & 180 & 3.32 & .571 & 118.98 & 21416.5 & & \\
& not subject to 657 & 74 & 3.53 & .539 & 148.22 & 10968.5 & & \\
\hline
\end{tabular}

As shown in the table, participants' affective commitment levels do not statistically significantly differ on the basis of their employment status $(p>0.05)$, and their continuance, normative and organizational commitment levels statistically significantly differ based on the same criteria $(p<0.05)$. Continuance, 
normative and organizational commitment scores of participants subject to law no 657 is higher than those who are not subject to law no 657.

\section{Table 4.}

Descriptive Statistics Related to the Participants' Organizational Citizenship Questionnaire Scores

\begin{tabular}{llll}
\hline Sub-dimensions & $N$ & $X$ & $S S$ \\
\hline Cooperativeness & 254 & 4.37 & .512 \\
Volunteering & 254 & 4.37 & .471 \\
Civic virtue & 254 & 4.04 & .608 \\
Improved sense of duty & 254 & 4.08 & .595 \\
\hline
\end{tabular}

The participants were found to have high levels of cooperativeness and volunteering scores and moderate levels of civic virtue and improved sense of duty scores.

\section{Table 5 .}

Comparison of Organizational Citizenship Questionnaire Scores of Participants Based on Their Educational Status

\begin{tabular}{|c|c|c|c|c|c|c|c|}
\hline Sub-dimension & Edu. Status & $N$ & $X$ & SS & $\begin{array}{l}\text { Rank } \\
\text { Ave. }\end{array}$ & $x^{2}$ & $p$ \\
\hline \multirow{3}{*}{ Cooperativeness } & Associate deg. & 19 & 4.39 & .514 & 129.11 & \multirow{3}{*}{.010} & \multirow{3}{*}{.995} \\
\hline & Bachelor's deg. & 217 & 4.37 & .513 & 127.37 & & \\
\hline & Master's deg. & 18 & 4.37 & .524 & 127.33 & & \\
\hline \multirow{3}{*}{ Volunteering } & Associate deg. & 19 & 4.32 & .545 & 122.47 & \multirow{3}{*}{.373} & \multirow{3}{*}{.830} \\
\hline & Bachelor's deg. & 217 & 4.37 & .466 & 127.21 & & \\
\hline & Master's deg. & 18 & 4.43 & .476 & 136.36 & & \\
\hline \multirow{3}{*}{ Civic virtue } & Associate deg. & 19 & 4.18 & .588 & 141.66 & \multirow{3}{*}{3.916} & \multirow{3}{*}{.141} \\
\hline & Bachelor's deg. & 217 & 4.00 & .605 & 123.93 & & \\
\hline & Master's deg. & 18 & 4.28 & .618 & 155.56 & & \\
\hline \multirow{2}{*}{$\begin{array}{l}\text { Improved sense of } \\
\text { duty }\end{array}$} & Associate deg. & 19 & 4.16 & .514 & 132.24 & \multirow{2}{*}{3.855} & \multirow{2}{*}{.145} \\
\hline & Bachelor's deg. & 217 & 4.06 & .598 & 124.48 & & \\
\hline
\end{tabular}




$\begin{array}{lllll}\text { Master's deg. } & 18 & 4.33 & .605 & 158.89\end{array}$

As indicated by the table, the cooperativeness, volunteering, civic virtue and improved sense of duty scores of the participants do not statistically significantly differ on the basis of their educational status $(p>0,05)$.

\section{Table 6.}

Comparison of Organizational Citizenship Questionnaire Scores of Participants Based on Their Employment Status

\begin{tabular}{|c|c|c|c|c|c|c|c|c|}
\hline Sub dimensions & İstihdam biçimi & $N$ & $X$ & SS & $\begin{array}{l}\text { Rank } \\
\text { ave. }\end{array}$ & $\begin{array}{l}\text { Rank } \\
\text { total. }\end{array}$ & $x 2$ & $p$ \\
\hline \multirow[b]{2}{*}{ Cooperativeness } & subject to 657 & 180 & 4.38 & .519 & 127.76 & 22997.5 & \multirow[b]{2}{*}{6612.5} & \multirow[b]{2}{*}{.928} \\
\hline & not subject to 657 & 74 & 4.37 & .499 & 126.86 & 9387.5 & & \\
\hline \multirow[b]{2}{*}{ Volunteering } & subject to 657 & 180 & 4.39 & .475 & 131.67 & 23701.0 & \multirow[b]{2}{*}{5909.0} & \multirow[b]{2}{*}{.148} \\
\hline & not subject to 657 & 74 & 4.31 & .460 & 117.35 & 8684.0 & & \\
\hline \multirow{2}{*}{ Civic virtue } & subject to 657 & 180 & 4.05 & .608 & 128.98 & 23216.5 & \multirow{2}{*}{6393.5} & \multirow{2}{*}{.613} \\
\hline & not subject to 657 & 74 & 4.01 & .610 & 123.90 & 9168.5 & & \\
\hline \multirow{2}{*}{$\begin{array}{l}\text { Improved sense } \\
\text { of duty }\end{array}$} & subject to 657 & 180 & 4.06 & .625 & 125.50 & 22590.0 & \multirow{2}{*}{6300.0} & \multirow{2}{*}{.492} \\
\hline & not subject to 657 & 74 & 4.14 & .515 & 132.36 & 9795.0 & & \\
\hline
\end{tabular}

As shown in the table, the participants' cooperativeness, volunteering, civic virtue and improved sense of duty scores do not statistically significantly differ on the basis of their employment status $(p>0.05)$.

\section{Table 8 .}

Investigation of the Relationship Between Organizational Commitment Questionnaire and Organizational Citizenship Questionnaire Scores of Participants

\begin{tabular}{llllll}
\hline & & Cooperativeness Volunteering & Civic virtue & $\begin{array}{l}\text { Improved sense of } \\
\text { mission }\end{array}$ \\
\hline Affective commit. & $r$ & $.267^{* *}$ & $.334^{* *}$ & $.359^{* *}$ & $.184^{* *}$ \\
& $p$ & .000 & .000 & .000 & .003 \\
Continuan.commit. & $r$ & $.185^{* *}$ & .112 & $.160^{*}$ & $.175^{* *}$ \\
\hline
\end{tabular}




\begin{tabular}{llllll}
\hline & $p$ & .003 & .076 & .010 & .005 \\
Normative commit. & $r$ & $.144^{*}$ & $.125^{*}$ & $.251^{* *}$ & $.202^{* *}$ \\
& $p$ & .022 & .046 & .000 & .001 \\
Organizat.commit & $r$ & $.267^{* *}$ & $.257^{* *}$ & $.345^{* *}$ & $.250^{* *}$ \\
& $p$ & .000 & .000 & .000 & .000 \\
\hline
\end{tabular}

A linear relationship under moderate level $(p<0.05)$ was found among cooperativeness, volunteering and civic virtue dimensions; and a linear and low level of significant correlation $(p<0.05)$ was found between affective commitment and improved sense of duty dimensions. A linear and low level of significant relationship $(p<0.05)$ was found among continuance commitment, cooperativeness, civic duty and improved sense of duty; whereas no significant relation was found between continuance commitment and volunteering $(p>0.05)$. There is a linear and low correlation level $(p<0.05)$ between normative commitment and volunteering. A linear and low level of significant relationship was found between normative commitment, and cooperativeness and volunteering $(\mathrm{p}<0.05)$, and a linear relationship under moderate level was found between normative commitment, and civic virtue and improved sense of duty $(\mathrm{p}<0,05)$. A linear relationship under moderate level was found between organizational commitment and, civic virtue and improved sense of duty $(p>0.05)$.

\section{DISCUSSION}

The participants' level of affective commitment was observed to be under moderate level, whereas they were found to have moderate level of continuance commitment, normative commitment and organizational commitment. These findings are indicative of the participants' high affective satisfaction levels within their organizations. However, the moderate levels of continuance commitment indicate that the employees are not sufficiently satisfied by the working conditions in their organizations. The moderate level of normative commitment is attributed to the moderate level of continuance commitment among the participants.

In Çoban's (2015) study, teachers' level of affection and continuance commitment were found to be higher than moderate, their normative commitment was found to be moderate and their organizational commitment was found to be lower than moderate. In the same research, participants' level of affection, continuance, normative and organizational commitment was found to be statistically significantly different from each other. The difference between affection and organizational commitment was ascribed to the higher commitment levels of participants with an associate and/or master's degrees as compared to those with a bachelor's degree. The difference between continuance and normative commitment was attributed to the higher commitment levels of participants with an associate degree as compared to those with a bachelor's degree.

Taşkın and Dilek (2010) reported that, increasing educational status resulted with increased levels of affection commitment and decreased levels of continuance commitment. In the same research, affection 
commitment of the teachers was found to exhibit no difference based on their employment status whereas their continuance, normative and organizational commitment significantly differed on the basis of their employment status. In terms of affection, continuance, normative and organizational commitment, participants subject to law no 657 exhibited higher commitment levels.

In the present research, teachers exhibited high levels of cooperativeness and volunteering and moderate levels of civic virtue and improved sense of duty. These findings are indicative of the good citizenship level of the participants in their organization. Organizational citizenship levels can be improved through the policies implemented by managers, and accordingly a better working environment within the organization can be provided (Karaman \& Ayhan, 2012). In this frame, school managers should be encouraged to receive trainings on how to improve their organizational citizenship levels and wellfunctioning rewarding systems should be established for successful teachers (Titrek et al., 2009). According to Yeşiltaş and Keleş (2009) citizens with better levels of organizational commitment are more likely to be satisfied by their jobs, resulting with increased levels of motivation and integration with their organization.

In this research, teachers' level of cooperativeness, volunteering, civic virtue and improved sense of duty was found to not significantly differ on the basis of their educational status. Likewise, the findings of Titrek et al. (2009) indicate that, teacher's organizational citizenship levels did not significantly differ on the basis of their educational status. In the same research, the participants with a bachelor's and/or master's degree exhibited higher levels of organizational citizenship in altruism, scrupulosity and civic virtue dimensions and lower levels of commitment in kindness dimension as compared to the participants with a high school and/or associate degree.

A linear significant relationship under moderate level was found between affection commitment level, and cooperativeness, volunteering and civic virtue level, and a low level of linear significant relationship was found between affection commitment and improved sense of duty dimension. A low level of linear and significant relationship was found between continuance commitment, and cooperativeness, civic virtue and improved sense of duty dimensions; however no significant relationship was found between continuance commitment and volunteering dimension. A low level of linear significant relationship was found between normative commitment, and cooperativeness and volunteering dimensions; whereas a linear and significant relationship under moderate level was observed between normative commitment and civic virtue and improved sense of duty dimensions. A linear and significant relationship under moderate level was observed between organizational commitment, and cooperativeness, volunteering and improved sense of duty sub-dimensions.

In conclusion, the participating teachers' organization commitment levels were found to significantly differ on the basis of their employment and educational status; while no significant difference was observed in organizational citizenship behavior based on educational and employment status. In general, the findings obtained from the study were found to be in good agreement with literature results. Further studies should be carried out to obtain more in-depth information on the citizenship and organizational commitment levels of pre-school teachers. 


\section{REFERENCES}

Al, A. (2007). Üniversitelerdeki yabancı diller birimleri yöneticilerinin yönetsel yeterlik düzeyi ile ingilizce öğretim elemanlarının örgütsel bă̆lılık düzeylerinin araştırılması (Yayınlanmamış yüksek lisans tezi). Kocaeli Üniversitesi Sosyal Bilimler Enstitüsü, Kocaeli.

Arslan, H., \& Önce, M. (2014). Yerel yönetimlerde çalışanların örgütsel bağlılı̆̆ı üzerine bir inceleme: Çankırı Belediyesi örneği. Insan ve Toplum Bilimleri Araştırmaları Dergisi, 3(3), 571-587.

Bakan, İ. (2011). Örgütsel stratejilerin temeli örgütsel bağlılık. Ankara: Gazi Kitabevi.

Balay, R. (2000). Yönetici ve öğretmenlerde örgütsel bağlllık. Ankara: Nobel Yayın Dağıtım.

Basım, H., \& Şeşen, H. (2015). Örgütsel Vatandaşlık Davranışı Ölçeği uyarlama ve karşılaştırma çalışması. Ankara Üniversitesi SBF Dergisi, 61(4), 83-101.

Bayrak-Kök, S. (2006). İş tatmini ve örgütsel bağlılığın incelenmesine yönelik bir araştırma. İktisadi ve İdari Bilimler Dergisi, 20(1), 291-317.

Bolat, O. İ., \& Bolat, T. (2008). Otel işletmelerinde örgütsel bağlılık ve örgütsel vatandaşlık davranışı ilişkisi. Balıkesir Üniversitesi Sosyal Bilimler Enstitüsü Dergisi, 11(9), 75-94.

Can, A. (2014). SPSS ile bilimsel araştırma sürecinde nicel veri analizi (2. Baskı) Ankara: Pegem Akademi.

Çetin, F. (2011). Örgütsel vatandaşlık davranışlarının açıklanmasında örgütsel bağlılık, iş tatmini, kişilik ve örgüt kültürünün rolü (Yayınlanmamış Doktora Tezi). Ankara Üniversitesi Sosyal Bilimler Enstitüsü, Ankara.

Çoban, T. (2015). Okul kültürünün öğretmenlerin örgütsel bağlılıkları üzerindeki etkilerinin incelenmesi (Yayınlanmamış Yüksek Lisans Tezi). Türk Hava Kurumu Üniversitesi Sosyal Bilimler Enstitüsü, İstanbul.

Çöl, G., \& Gül, H. (2005). Kişilik özelliklerinin örgütsel bağlılık üzerine etkileri ve kamu üniversitelerinde bir uygulama. İktisadi ve İdari Bilimler Dergisi, 19(1), 291-306.

Demir, P. (2007). Aile şirketlerinde örgütsel vatandaşlık: Gaziantep uygulaması (Yayınlanmamış yüksek lisans tezi). Gaziantep Üniversitesi Sosyal Bilimler Enstitüsü, Gaziantep.

Demirel, Y. (2008). Örgütsel güvenin örgütsel bağlılık üzerine etkisi: Tekstil sektörü çalışanlarına yönelik bir araştırma. Yönetim ve Ekonomi, 15(2), 179-194.

Demirel, Y. (2009). Örgütsel bağlılık ve üretkenlik karşıtı davranışlar arasındaki ilişkiye kavramsal yaklaşım. İstanbul Ticaret Üniversitesi Sosyal Bilimler Dergisi, 8(15), 115-132.

Demirkol, A. Y. (2014). Eğitim kurumlarında örgütsel bağlılı: Meslek yüksekokulları üzerine bir araştırma. Ĕ̆gitim Bilimleri Araştırmaları Dergisi, 4(1), 1-15.

Doğan, N. (2009). Sını öğretmenlerinin duygusal zekâları ile örgütsel bağhllıkları arasındaki ilişki (İstanbul İli Anadolu Yakası örneği) (Yayınlanmamış yüksek lisans tezi). Maltepe Üniversitesi Sosyal Bilimler Enstitüsü, İstanbul. 
Doğan, S., \& Kılıç, S. (2007). Örgütsel bağlllığın sağlanmasında personel güçlendirmenin yeri ve önemi. Erciyes Üniversitesi İktisadi ve İdari Bilimler Fakültesi Dergisi, 29, 37-61.

Durna, U., \& Eren, V. (2005). Üç bağlllık unsuru ekseninde örgütsel bağlllık. Doğuş Üniversitesi Dergisi, 6(2), 210-219.

Eren, H., \& Demirgöz-Bal, M. (2015). Hemşirelikte örgütsel bağlllık. Sağglk ve Hemşirelik Yönetimi Dergisi, $1(2), 44-50$.

Güçel, C. (2013). Örgütsel bağlllığın örgütsel vatandaşlık davranışına etkisi örgütsel adaletin aracılık rolü: İmalat işletmelerine yönelik bir araştırma. İşletme Araştırmaları Dergisi, 5(2), 173-190.

İlısu, İ. (2012). Personel güçlendirmenin örgütsel vatandaşlık davranışı ve işten ayrlma niyetine etkisi üzerine bir araştırma (Yayınlanmamış yüksek lisans tezi). Niğde Üniversitesi Sosyal Bilimler Enstitüsü, Niğde.

Kaplan, İ. (2011). Örgütsel vatandaşlık davranışı ve iş tatmini ilişkisi; Konya Emniyet Teşkilatı üzerinde bir uygulama (Yayınlanmamış Doktora Tezi). Selçuk Üniversitesi Sosyal Bilimler Enstitüsü, Konya.

Karaman, A., \& Aylan, S. (2012). Örgütsel vatandaşlık. Kahramanmaraş Sütçü İmam Üniversitesi İktisadi ve İdari Bilimler Fakültesi Dergisi, 2(1), 35-48.

Meyer, J. P., \& Allen, N. J. (1991). A three-component conceptualization of organizational commitment. Human Resource Management Review, 1(1), 61-89.

Meyer, J. P., Allen, N. J., \& Smith, C. A. (1993). Commitment to organizations and occupations: Extension and test of a three component conceptualization. Journal of Applied Psyhology, 78(4), 538551.

Seyhan, M. (2014). İşletmelerde örgütsel bağlllık ve örgütsel bağlllı̆̆ı etkileyen faktörler: Gümrük memurları üzerine bir araştırma (Yayınlanmamış yüksek lisans tezi). Trakya Üniversitesi Sosyal Bilimler Enstitüsü, Edirne.

Taşkın, F., \& Dilek, R. (2010). Örgütsel güven ve örgütsel bağlılık üzerine bir alan araştırması. Organizasyon ve Yönetim Bilimleri Dergisi, 2(1), 37-46.

Titrek, O., Bayrakçı, M., \& Zafer, D. (2009). Öğretmenlerinin örgütsel vatandaşlık davranışlarına ilişkin görüşleri. Akademik Bakış, 17, 1-28.

Yazıcıŏ̆lu, İ., \& Topaloğlu, I. G. (2009). Örgütsel adalet ve bağlllık ilişkisi: Konaklama işletmelerinde bir uygulama. İşletme Araştırmaları Dergisi, 1(1), 3-16.

Yeşiltaş, M., \& Keleş, Y. (2009). İşgörenlerin eğitim düzeyleri ve örgütsel vatandaşlık davranışları arasındaki ilişkinin incelenmesine yönelik bir araştırma. Gazi Üniversitesi İktisadi ve İdari Bilimler Fakültesi Dergisi, 11(2), 17-40. 